\title{
Cultural sociology in the Australian context
}

\section{Eduardo de la Fuente}

Monash University

\author{
Brad West \\ Flinders University
}

This 'Cultural Sociology' special issue of the Journal of Sociology comes at a significant time in the development of cultural sociological analysis. Culture sections are thriving within North American, British and European sociological associations and the Cultural Sociology Group has established itself as amongst the most popular thematic sections in The Australian Sociological Association. Culture is also the subject of a burgeoning sociological literature. This includes the establishment of the journal Cultural Sociology, the first international sociology periodical exclusively dedicated to the examination of cultural matters.

The emergence of cultural sociology as a sub-discipline can be understood in reference to a broader 'cultural turn' in the social sciences. In sociology this has had two implications. Where cultural spheres such as the media, popular culture, art, music, fashion, consumption and lifestyle were once not considered a basis for serious sociological scholarship (Zolberg, 1989), there is now a widespread appreciation of their importance in shaping the economy, politics and the conduct of public life (Lash and Urry, 1994). The 'cultural turn' has also seen the integration of cultural theories, concepts and methods into mainstream sociology. As the editors of a recent sociological collection on 'matters of culture' surmise, '[w] here sociologists once spurned culture', today they embrace problems and topics 'traditionally within the humanist's purview ... [and] increasingly emphasize the role of meanings, symbols, cultural frames, and cognitive schema' (Friedland and Mohr, 2004: 1). The linguistic and semiotic analysis of French structuralism, in particular, has provided a vocabulary for the emergence of a more cultural form of the 'sociological imagination' that avoids the reductionism of both grand systems functionalism and purely materialist understandings of social life.

Journal of Sociology @ 92008 The Australian Sociological Association, Volume 44(4): 315-319 DOI:10.1177/1440783308097122 www.sagepublications.com 
Despite the influence of cultural analysis in shaping the contemporary understanding of the sociological pursuit, cultural sociology continues to see itself as a sub-section existing at the margins of the discipline (Jacobs and Spillman, 2005). This is reinforced by two identity markers: emphasis on the interdisciplinary character of cultural sociology scholarship, utilizing theorists in other fields such as anthropology, history and literary criticism; and contrasts made with the discipline as a positivistic enterprise. The selfidentification as an 'outsider' has helped establish a sense of unity for cultural sociology; however, this hides unresolved tensions regarding the very nature of the field. Apart from traditional methodological and epistemological divides found in the discipline more broadly - between micro and macro analysis, agency and structural consideration - cultural sociologists have been in debate about the power of culture itself and its relationship to the social (de la Fuente, 2007; Rojek and Turner, 2000).

One of the major divides is between the application of sociology to cultural matters and the felt need for sociology to incorporate cultural sensitivities in its analysis. For example, the first significant burst of activity in the field developed under the rubric of the 'production of culture' perspective. In the pioneering work of Richard Peterson, Diana Crane and Howard Becker, cultural fields such as art, music, fashion and science were explained by classic sociological variables such as rewards, institutional structures and status distinctions. This perspective generated a significant amount of empirical research into how 'cultural worlds' function, but it came to be seen by critics as reductionist and as unable to deal with the semiotic and meaningful properties of culture. Others have argued that cultural sociology requires a more meaning-centred framework. Jeffrey Alexander (2003; forthcoming), for example, has articulated that the project of cultural sociology is distinct from the sociology of culture, and at its core should be cultural variables such as codes, narratives, rituals, performances and - in his most recent writings - 'iconicity', which can be applied to all dimensions of social life, even those typically explained in relation to material and economic forces.

In the everyday practice of cultural sociology, however, these divisions tend to be less trenchant with recognition of various intellectual traditions of cultural analysis. Rather than being actively engaged in programmatic debates, most scholars in the field are concerned with empirical discovery and middle-range theorizing. This is evident in the contributions to this special issue of the Journal of Sociology, with a key characteristic being calls for more sober accounts of contemporary society. For Katie Wright, this involves challenging the pessimistic assessments of therapeutic culture, illustrated in the advent of telephone counselling in the 1960s and the Royal Commission on Human Relationships in the 1970s. Brad West's narrative analysis of the 2002 Bali bombing, and John Budarick and Debra King's study of the Sydney Redfern riots, point to the need for detailed examination 
of the discursive construction of cultural trauma, the multiple voices evident in civil society and their role in re-imagining collective identities. Where the above-mentioned studies use accepted discursive methods of cultural analysis, the article by Bruce Tranter and Jed Donoghue on Australian bushranger mythology, and Timothy Phillip and Philip Smith's on cosmopolitanism, evidence the contribution that quantitative survey methodologies can make to cultural sociology. This methodological perspective attempts to move beyond representations of reality, being directly concerned with attitudes, beliefs and actions. The advantage of this approach is that it raises important questions of validity, reliability, and generalizability (Phillips, 1998; Smith and West, 2003), in these cases concerning national identity and global consciousness. Gavin Kendall, Zlatko Skrbis and Ian Woodward reinforce the need for such systematic study in this area, illustrating that the scholarship on cosmopolitanism has been dominated by romantic and individualistic notions that neglect existing cultural attachments. The special issue of the journal concludes with Andy Bennett's contribution on what a cultural sociology can offer the study of popular music. In his article, Bennett addresses the complex question of how cultural sociology should be differentiated from traditional cultural studies approaches which, he argues, have an overly textual bias.

As a showcase of cultural sociology being undertaken in Australia, this special issue inevitably raises the question of what is distinctly 'Australian' about this scholarship? Given the recent formation of the Cultural Sociology Group in The Australian Sociological Association, it maybe premature to speak in great detail regarding the distinctive characteristics of Australian cultural sociology as it emerges as an institutional entity. However, we can point to a number of particular characteristics and possibilities.

While, in a global context, Australia has a small intellectual community, it can be thought to have punched above its weight with significant contributions to cultural sociology by intellectuals such as Anthony Elliott, Peter Beilharz, John Carroll, Peter Corrigan, Stephen Crook, Mike Emmison, Joanne Finkelstein, Adrian Franklin, Paul Jones, Deborah Lupton, Jim McKay, David Rowe, Philip Smith, Deborah Stevenson and Claudio Veliz. Australia has also generated an interesting younger generation of cultural sociologists who have engaged and critiqued the theories and methods of cultural sociology, often in relation to Australian subject matter, including such figures as Douglas Ezzy, Margaret Gibson, Brett Hutchins, Timothy Philips, Adam Possamai, Brad West, Raelene Wilding and Ian Woodward. This intellectual map has consisted of particular centres of established and emerging cultural sociological excellence. Traditionally, cultural sociological reflection has been strong in sociology departments at La Trobe, the University of Queensland and the University of Tasmania, and in recent years has been gaining significant traction at Flinders University and at Griffith University. 
The strength of this scholarship has been its theoretical and methodological plurality, utilizing a diversity of international intellectual perspectives. Unlike cultural sociology in North America and Britain, which have developed in relative isolation from each other (Smith, 1998), Australian cultural sociology has generally worked between these national traditions, while joining them in engaging with European social theories. This is exemplified by the fact that the articles contained in this special issue cite theorists as diverse as Jeffrey Alexander, Zygmunt Bauman, Ulrich Beck, David Chaney, Clifford Geertz, Stuart Hall, Richard Peterson, Philip Rieff and Victor Turner. In this way Australian cultural sociology is also differentiated from Australian cultural studies, which has traditionally influenced British cultural studies. ${ }^{1}$

In identifying these foreign influences we concur with Connell (2007) that Australian sociology has been traditionally caught in a dynamic that sees it attracted to the poles of 'metropolitanism' and 'parochialism'. However, the articles contained in this special issue highlight that it is possible both to be Australian-focused and to transcend the limitations of nation-state. Our argument would be that the analyses contained here are not simply an application of some free-floating global sociology to Australian culture and identity. Rather, they are examples of how the Australian context provides historically and socially distinctive cases for challenging and revising sociological theories and methods. Cultural sociological reflection, by its very nature, is grounded in place, tradition and history. Thus, even those articles in the volume that don't directly address Australian subject matter speak to the possibility of an Australian cultural sociology through their style of analysis and in questioning universalistic assumptions. In doing so, these reflections on cultural 'particulars' shed fresh light on topics of universal significance such as cosmopolitanism, cultural production, nationalism, the social crisis, terrorism and therapeutic consciousness.

\section{Note}

1 In contrast to the Australian case, cultural sociology in Britain has largely chosen to locate its origins with cultural studies as undertaken at the Centre for Contemporary Cultural Studies (CCCS) at the University of Birmingham. David Inglis has argued that in Britain the two fields are united by an identifiable 'metadiscourse' (Inglis, 2007).

\section{References}

Alexander, J.C. (2003) The Meanings of Social Life: A Cultural Sociology. New York: Oxford.

Alexander, J.C. (forthcoming) 'Iconic Experience in Art and Life: Surface/Depth Beginning with Giacometti's "standing woman"', Theory, Culture and Society.

Connell, R. (2007) Southern Theory: The Global Dynamics of Knowledge in Social Science. Crows Nest, NSW: Allen and Unwin. 
de la Fuente, E. (2007) 'The Place of Culture in Sociology: Romanticism and Debates about the Cultural Turn', Journal of Sociology 43(2): 115-30.

Friedland, R. and J. Mohr (2004) 'The Cultural Turn in American Sociology', in R. Friedland and J. Mohr (eds) Matters of Culture: Cultural Sociology in Practice. Cambridge: Cambridge University Press.

Inglis, D. (2007) 'The Warring Twins: Sociology, Cultural Studies, Alterity and Sameness', History of the Human Sciences 20(2): 99-122.

Jacobs, M.D. and L. Spillman (2005) 'Cultural Sociology at the Crossroads of the Discipline', Poetics 33: 1-14.

Lash, S. and J. Urry (1994) Economies of Signs and Space. London: SAGE.

Phillips, T. (1998) 'Popular Views about Australian Identity', Journal of Sociology 34(3): 281-302.

Rojek, C. and B. Turner (2000) 'Decorative Sociology: Towards a Critique of the Cultural Turn', Sociological Review 48(4): 629-48.

Smith, P. (1998) 'Introduction', pp. 1-14 in The New American Cultural Sociology. Cambridge: University Cambridge Press.

Smith, P. and B. West (2003) 'Cultural Studies, Australian Studies and Cultural Sociology', pp. 638-53 in I. McAllister, S. Dowrick and R. Hassan (eds) Cambridge Handbook of the Social Sciences in Australia. Melbourne: Cambridge University Press.

Zolberg, V. (1990) Constructing a Sociology of the Arts. Cambridge: Cambridge University Press.

\section{Biographical notes}

Eduardo de la Fuente teaches in the Communications and Media Studies program at Monash University. Since 2005, he has been a Faculty Fellow of the Center for Cultural Sociology, Yale University, and Co-Convenor of the TASA Cultural Sociology Thematic Group. His work lies at the intersection of cultural sociology and communication studies, and he has published articles on the sociology of art, the 20th-century composer, Romanticism in the social sciences, aesthetics and everyday life, and has a forthcoming monograph on 20th-century music and the question of cultural modernity. Address: School of English, Communications and Performance Studies, Monash University, Clayton, VIC 3800, Australia. [email: Eduardo.delaFuente@arts.monash.edu.au]

Brad West is a Senior Lecturer in the Department of Sociology at Flinders University and founding Co-Convenor of the Cultural Sociology Thematic Group in The Australian Sociological Association. Largely working from a Durkheimian cultural framework, much of his recent research has examined the ability of national history and identity to be re-enchanted through the logics of leisure, tourism and consumption. This work has appeared in such journals as Sociological Theory (2008), Tourist Studies (2006) and Journal of Popular Culture (2002). Address: Department of Sociology, Flinders University, GPO Box 2100, Adelaide 5001, Australia. [email: Brad.West@flinders.edu.au] 